Health Organization, and the East, Central, and Southern Africa Health Community are actively exploring such collaboration. Experience from the eastern Caribbean and the Gulf States has already shown the potential savings and sustainability of such arrangements. ${ }^{11}$

The current systems for pharmaceutical supply in many parts of Africa are overwhelmed. Policy makers and healthcare managers must fundamentally change their thinking. The real challenge is to identify, select, and implement the best solutions for each country's situation. As the conference in June on strategies for enhancing access to medicines concluded, "Africa is learning in its own way how its own forms of private and public enterprise can work together in the particular way that Africa needs."12

Jonathan D Quick president and chief executive officer (jquick@msh.org)

Nana-Adjoa Boohene senior programme associate Management Sciences for Health, 784 Memorial Drive, Cambridge, MA 02139, USA

James Rankin director, Center for Pharmaceutical Management

Management Sciences for Health, 4301 N Fairfax Drive, Suite 400, Arlington, VA 22203, USA

Romuald J Mbwasi senior technical adviser

Management Sciences for Health, ASG Building Nyerere Road, PO Box 50104, Dar es Salaam, Tanzania
We are grateful for the assistance of Martha Embrey, David Lee, and Keith Johnson in the preparation of this editorial.

Competing interests: None declared.

1 Global Fund for HIV/AIDS, Tuberculosis and Malaria. HIV/AIDS, tuberculosis and malaria: the status and impact of the three diseases. Geneva: Global Fund, 2005

2 Black RE, Morris SS, Bryce J. Where and why are 10 million children dying every year? Lancet 2003;361:2226-34.

3 Quick JD. Essential medicines twenty-five years on: closing the access gap. Health Policy Plan 2003; 18:1-3.

4 World Health Organization. WHO medicines strategy: countries at the core 2004-2007. http://whqlibdoc.who.int/hq/2004/WHO_EDM_2004.5.pdf (accessed 26 Sep 2005).

5 UN Millennium Project. Prescription for healthy development: increasing access to medicines. Sterling, VA: Earthscan, 2005. (Report of the Task Force on HIV/AIDS, Malaria, TB, and Access to Essential Medicines, Working Group on Access to Essential Medicines.)

6 WHO. The world medicines situation. Geneva: World Health Organization, 2004. www.eldis.org/static/DOC17161.htm (accessed 22 Sep 2005).

7 Chen L, Evans T, Anand S, Boufford JI, Brown H, Chowdhury M, et al. Human resources for health: overcoming the crisis. Lancet 2004; 364:1984-90.

8 Kawasaki E, Patten JP. Drug supply systems of missionary organizations identifying factors affecting expansion and efficiency: case studies from Uganda and Kenya. Prepared for WHO/EDM. 2002. (World Health Organization \#HQ/01191467.)

9 Mbwasi R. Using a holistic approach to transform private sector drug outlets: the Tanzania experience. Presented at the Strategies for Enhancing Access to Medicines Conference, Accra, Ghana 20-22 June 2005. www.msh.org/seam/conference2005 (accessed 22 Sep 2005).

10 Management Sciences for Health. Drug supply strategies. In: Managing drug supply. 2nd ed. Bloomfield, CT: Kumarian Press, 1997.

11 Center for Pharmaceutical Management. Regional pooled procurement of drugs in sub-Saharan Africa.. Arlington, VA: Management Sciences for Health, 2002. (Produced for Rockefeller Foundation.)

12 Dukes, G. Moving forward-now! Presented at the Strategies for Enhancing Access to Medicines Conference, Accra, Ghana, 20-22 June 2005. www.msh.org/seam/conference2005 (accessed 22 Sep 2005).

\title{
Road safety in Africa
}

\section{Is part of the broader development process}

We must now use every day to act on road safety, and implement effective sustainable action to prevent injury and death on the world's roads.

Dr Lee Jong-wook, director-general, World Health Organization

$\mathrm{T}$ The World Report on Road Traffic Injury Prevention notes that political will and commitment are important for sustainable prevention of road traffic injuries. ${ }^{1}$ Development agencies need to place road safety in Africa and elsewhere at the centre of the global agenda along with the institutional, political, economic, and social issues which make roads so dangerous. For example, the World Summit on Sustainable Development held in Johannesburg, South Africa, in September 2002 did not include a single item on road safety-a growing problem in Africa and other low income and middle income countries-on its agenda, declaration, or plan of action. ${ }^{2}$

Africa's economic and social conditions began to deteriorate in the 1970 s and have continued to do so. ${ }^{34}$ Between 1990 and 2002, the gross national income per capita grew at an annual average of $0.5 \%$ for all Africa and $0.02 \%$ for sub-Saharan Africa. ${ }^{5}$ Africa is faced with declining agricultural output, foreign debt burden, unemployment, poorly performing industry, deteriorating healthcare systems, HIV/AIDS, environmental insecurity, and political instability. ${ }^{6}$ This is the context in which the problem of road safety has to be addressed. Several issues require reflection and action. How does the prevailing economic situation in Africa affect the amount of resources devoted to road safety? In what ways does the political setting that has been characterised by instability in many countries affect development of institutions and capacity for road safety and other sectors? Bishai and colleagues show that budgetary expenditure on road safety at all levels of government in Uganda is US $\$ 0.09$ per capita. ${ }^{7}$ This problem of low and negligible resource allocation to road safety in Africa needs to be addressed: at the moment, funding for road safety activities in Africa is very limited, a mere drop in the ocean.

Road transport can contribute to the socioeconomic development of Africa through facilitating movement of goods and people, opening up isolated areas, and promoting trade. ${ }^{8}$ Intricate movement patterns involve short, medium, and long distances, different modes of transport, and interaction within and between different places in Africa. ${ }^{8}$ The number of motor vehicles, volume of road traffic, and utilisation of the road by different road users in Africa have grown noticeably. The bicycle is increasingly used for passenger and freight transport in urban and rural areas. ${ }^{9}$ These transport characteristics indicate the need to pay adequate attention to safety measures in road transport development, especially safety of urban and 
rural communities living within the vicinity of roads. Development aid meant for road building takes no account of road safety, and there seems to be neglect of the fact that thousands will die and many more thousands will be injured while using roads in Africa and other parts of the world.

Under-reporting of road traffic injury is a major problem in Africa and virtually all countries of the world. ${ }^{110}$ About 200000 people died on African roads in 2002, ${ }^{1}$ and probably many more but we do not have an accurate picture because of the problem of under-reporting. A large proportion of those affected are pedestrians and passengers on public transport. ${ }^{111}{ }^{12}$ Institutional and economic factors that lead to the problem of under-reporting need to be addressed. Governments and development partners need to take practical steps to improve data collection, analysis, and sharing among different agencies.

The lesson we have learnt from our practical experience in supervising implementation of road safety projects in low income and middle income countries, including Africa, is that road safety has a socioeconomic and political context. Real progress can be made if development agencies and governments deal realistically with this context. Road safety is no accident: it is the result of deliberate efforts by many sectors of society, both governmental and nongovernmental, that have acknowledged it to be an important and valuable public good and have developed policies and programmes to support and maintain it. Development agencies, governments and non-governmental organizations need to allocate financial and human resources to address the road safety problem; identify and support a lead agency with authority and responsibility to guide national road safety efforts; prepare or revisit national road safety strategies and plans of action; implement specific actions such as enforcement of road safety regulations on speed and alcohol; and improve data collection on road traffic crashes in Africa. The time for action is now.

Meleckidzedeck Khayesi technical officer

(khayesim@who.int)

Margie Peden coordinator, unintentional injury prevention

Department of Injuries and Violence Prevention, World Health Organization, 20 Avenue Appia, CH-1211 Geneva, Switzerland

Competing interests: None declared.

1 Peden M, Scurfield R, Sleet D, Mohan D, Hyder AH, Jarawan E, et al. World report on road traffic injury prevention. Geneva: World Health Organization, 2004. www.who.int/world-health-day/2004/infomaterials world_report/en/ (accessed 22 Sep 2005).

2 United Nations. The road from Johannesburg: what was achieved and the way forward. New York: United Nations, Department of Economic and Social Affairs, 2003.

3 Darkoh MBK. Sub-Saharan Africa in crisis and the need for a new domestic order. In: Yeung Y, ed. Global change and the commonwealth. Hong Kong: Hong Kong Institute of Asia Pacific Studies, Chinese University of Hong Kong, 1996:45-65.

4 World Bank. Sub-Saharan Africa:from crisis to sustainable growth. Washington, DC: World Bank, 1989.

World Bank. African development indicators 2004. Washington, DC: World Bank, 2004.

Sachs J. The end of poverty: economic possibilities for our time. New York: Penguin Press: 2005.

7 Bishai D, Hyder AA, Ghaffar A, Morrow RH, Kobusingye O. Rates of public investment for road safety in developing countries: case studies of public investment for road safety in developing countries:

8 Alila P, Khayesi M, Odhiambo W, Pedersen PO. Development of African freight transport-the case of Kenya. Copenhagen: Danish Institute for International Studies, 2005. (Working paper No 2005/6.)

9 Howe J. The headloading and footpath economy-walking in sub-Saharan Africa. World Transport Policy and Practice 2001;7(4):8-12.

10 Roberts I. Death on the road to international development. BMJ 2005;330:972

1 Nantulya VM, Muli-Musiime F. Kenva: uncovering the social determinants of road traffic accidents. In: Evans T, Whitehead D, Diderichsen $\mathrm{F}$, Bhuiya A, Wirth M, eds. Challenging inequities: from ethics to action. New

12 Odero W, Garner P, Zwi A. Road traffic injuries in developing countries: a comprehensive review of epidemiological studies. Trop Med Intl Health 1997:2:445-60.

\section{Tackling cardiovascular disease in Africa}

\section{Will need much more than just imported measures from more developed countries}

I $\mathrm{n}$ the past four decades Africa has witnessed increasing urbanisation and changing lifestyles, factors which have, in turn, raised the incidence of non-communicable chronic diseases, especially cardiovascular disease. At the same time social disintegration and inequality, compounded by the dwindling economy in many countries in sub-Saharan Africa, have seriously hindered the response to these non-communicable diseases. Moreover, communicable diseases are still rife, using up health resources, and actions to deal with communicable diseases have often been based on data from smaller studies, usually hospital based. The situation is cause for concern.

Cardiovascular disease has reached near epidemic proportions in Africa. According to the World Health Report 2002, cardiovascular disease accounted for 9.2\% of total deaths in the African region in 2001, and hypertension, stroke, cardiomyopathies and rheumatic heart disease were the most prevalent causes. ${ }^{1}$ such as myocardial infarction and angina are relatively uncommon in most parts of Africa, heart failure is often seen. The World Health Organization has reported that the number of disability adjusted life years lost to cardiovascular disease in sub-Saharan Africa rose from 5.3 million for men and 6.3 million for women in 1990 to 6.5 million and 6.9 million in 2000 , and could rise to 8.1 million and 7.9 million in 2010. Cardiovascular disease has higher mortality in developing countries than in developed ones, ${ }^{2}$ and affects younger people and women disproportionately.

Hypertension remains the most threatening risk factor, with national prevalences ranging between 15\% and $30 \%$ in adults. Extrapolations from studies in Nigeria and elsewhere indicate that $5 \%$ of deaths could be due to hypertension and that the reduction in attributable risk associated with treatment could be $2 \%$, over 10 times higher than in the United States.. The usual risk factors of obesity, smoking, heavy drinking, physical inactivity, and inappropriate diet are all 